\title{
Siew New Disease Reports \\ First report of black Sigatoka disease in banana caused by Mycosphaerella fijiensis on Reunion Island
}

\author{
A. Rieux ${ }^{1 *}$, B. Hostachy ${ }^{2}$, L. De Lapeyre de Bellaire ${ }^{3}$, Y. Martin ${ }^{4}$, G. Maratchia ${ }^{4}$, A-S. Dupuis ${ }^{4}$, R. loos ${ }^{5}$, C. Jeandel ${ }^{5}$ and J. \\ Hubert ${ }^{5}$ \\ ${ }^{1}$ CIRAD, UMR PVBMT, 97410, St Pierre, La Réunion, France.; ${ }^{2}$ Anses, LSV, 97410, St Pierre, La Réunion, France; ${ }^{3}$ CIRAD, \\ UPR GECO, F-34398 Montpellier, France; ${ }^{4}$ Chambre d'Agriculture de la Réunion, 97410, St Pierre, La Réunion, France; ${ }^{5}$ \\ ANSES Laboratoire de la Santé des Végétaux, Unité de Mycologie, 54220 Malzéville, France
}

*E-mail: adrien.rieux@cirad.fr

Received: 14 Dec 2018. Published: 04 Apr 2019.

Pseudocercospora fijiensis, the causal agent of black Sigatoka disease of banana (Musa spp.) (BLSD), is considered to be the major economic threat for banana cultivated for export (de Lapeyre de Bellaire et al., 2010). The disease has a worldwide distribution throughout the humid tropical regions and has been previously reported in the southwest Indian Ocean area: in 1993 in Mayotte and Comoros islands (Jones \& Mourichon, 1993), in Mauritius in 1996 (Soomary \& Benimadhu, 1997) and in Madagascar in 2000 (Jones, 2003). In December 2017, typical BLSD symptoms were observed in a Cavendish cv. Petite Naine crop located in Grand Etang municipality, St. Benoit (Site S1, Fig. 1) in the east-central area of Reunion Island. Typical early symptoms (stage 2 ) were 1-4 $\mathrm{mm}$ long brown streaks on the abaxial leaf surface, and typical older streaks (stages 3 and 4) were also observed (Figs. 2-3).

In March 2018, banana leaves bearing leaf spot symptoms were collected in the four following sites (Fig. 1): Grand Etang (S1), where potential BLSD symptoms were observed in December 2017, and Piton St Rose (S2), Anse des Cascades (S3) and Langevin (S4). At each site, four leaf fragments (A, B, C \& D) cut from different banana plants were sampled resulting in 16 distinct samples.

All leaf fragments were sent to the ANSES laboratory where molecular diagnostics was performed following the protocol developed by Arzanlou $e t$ al. (2007). Genomic DNA was extracted from ground leaf fragments displaying symptoms using the DNeasy Plant Mini Kit (Qiagen, Germany). The DNA extracts were used as templates for a real-time PCR assay designed to specifically detect the presence of $P$. fijiensis DNA. The presence of DNA from Pseudocerspora eumusae and P. musicola, two related ascomycetous fungi causing other banana leaf spot diseases, were also assessed using the protocol of Arzanlou et al. (2007). Both positive and negative controls were included in the assay and every sample reaction was duplicated.

Pseudocerspora fijiensis was detected in three of the four samples from Grand Etang (site S1, see Table 1). The three positive PCR products were sequenced and deposited in GenBank (Accession Nos. MK729105-
MK729107). No positive signal for $P$. fijiensis was found in the other three sites. To our knowledge, this is the first report of BLSD in Reunion Island. Interestingly, our results also showed co-infection with P. eumusae (Table 1). This observation is in accordance with the literature since $P$. eumusae, the fungus causing eumusae leaf spot disease was identified on Reunion Island in 2000 (Jones, 2003). Further investigation will be required to monitor the spread of BLSD on the island and to identify the origin of the populations responsible for the introduction of the disease from the first reports of BLSD in the southwest Indian Ocean area in the 1990's

\section{References}

Arzanlou M, Abeln ECA, Kema GHJ, Waalwijk C, Carlier J, de Vries I, Guzmán M, Crous PW, 2007. Molecular diagnostics for the sigatoka disease complex of banana. Phytopathology 97, 1112-1118. http://dx.doi.org/10.1094/phyto-97-9-1112

Jones D, 2003. The distribution and importance of the Mycosphaerella leaf spot diseases of banana. In: Jacome LL, Lepoivre P, Martin D, Ortiz R, Romero R, Escalant JV, eds. Proceedings of the 2nd International Workshop on Mycosphaerella Leaf Spot Diseases, 2002. San José, Costa Rica. https://www.bioversityinternational.org/e-library/publications/detail/ mycosphaerella-leaf-spot-diseases-of-bananas-present-status-and-outlook. Accessed 14 December 2018. http://dx.doi.org/10.1051/fruits/2010034

Jones DR, Mourichon X, 1993. Black leaf streak/black sigatoka disease. Musa Disease Fact Sheet, International Network for the Improvement of Banana and Plantain.

de Lapeyre de Bellaire L, Fouré E, Abadie C, Carlier J, 2010. Black Leaf Streak Disease is challenging the banana industry. Fruits 65, 327-342. Soomary S, Benimadhu SP, 1998. The Mycosphaerella leaf disease complex (MLDC) of banana in Mauritius. In Lalouette JA, Bachraz DY, Sukurdeep N, Seebaluck BD, eds. Proceedings of the Second Annual Meeting of Agricultural Scientists, 1997, Reduit, Mauritius. http://farc.gov mu.org/English/Documents/Policy\%20and\%20promotion/Publications/fina 1m97.pdf. Accessed 14 December 2018.

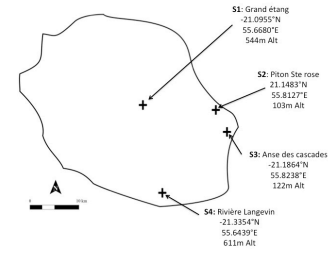

Figure 1

Table 1. Results of real-time PCR assays for samples from Grand Etang ( $\mathrm{S} 1$ ).

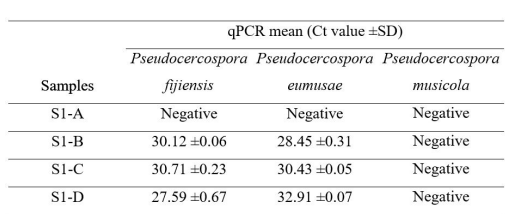

Figure 4

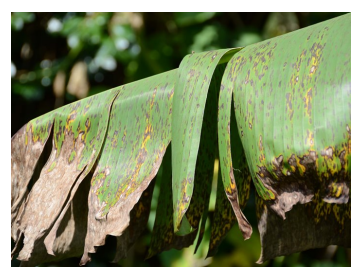

Figure 2

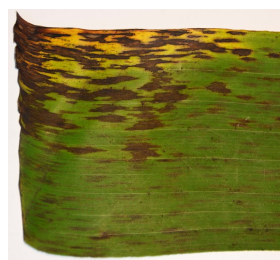

Figure 3

To cite this report: Rieux A, Hostachy B, De Lapeyre de Bellaire L, Martin Y, Maratchia G, Dupuis A, loos R, Jeandel C, Hubert J, 2019. First report of black Sigatoka disease in banana caused by Mycosphaerella fijiensis on Reunion Island. New Disease Reports $39,12$. http://dx.doi.org/10.5197/j.2044-0588.2019.039.012 